\title{
IDENTIFIKASI LOGAM BERAT Hg, Pb DAN Cd DI ALIRAN SUNGAI BATANG KUANTAN, KABUPATEN KUANTAN SINGINGI
}

\author{
Asregi Asril $^{1}$, Rosa Murwindra ${ }^{2}$, Jumriana Rahayuningsih ${ }^{3}$ \\ ${ }^{1}$ Fakultas Tarbiyah dan Keguruan,Universitas Islam Kuantan Singingi \\ Email asregi.asril@gmail.com \\ ${ }^{2}$ Fakultas Tarbiyah dan Keguruan,Universitas Islam Kuantan Singingi \\ Email rosamurwindra@gmail.com \\ ${ }^{3}$ Fakultas Tarbiyah dan Keguruan,Universitas Islam Kuantan Singingi \\ Email jumrianarahayuningsih1378@gmail.com
}

\begin{abstract}
The identification of heavy metals $\mathrm{Hg}, \mathrm{Pb}$ and $\mathrm{Cd}$ in the Batang Kuantan River, Kuantan Singingi Regency has been carried out successfully. Heavy metals are measured not only from their heavy metal content such as $\mathrm{Hg}, \mathrm{Pb}$ and $\mathrm{Cd}$ but also from the $\mathrm{pH}$ level of the river flow itself. The research location is at the Batang Kuantan River, which is measured from 3 points. Changes in Data Observed / Measured are the quality levels of heavy metals in the waters. The research model used includes field research using survey and laboratory methods. The research design was analyzed using the Atomic Absorption Spectometer (AAS). The water sample was given HNO3 until it was acidic and filtered so that there was no sedimentation, then analyzed by AAS. Heavy metal analysis result data technique is compared with quality standard of government regulation no 82 of 2001 regarding water pollution control and water quality management. Pb did not have a problem because the levels were not found. Whereas for $\mathrm{Cu}$ and $\mathrm{Cd}$ in the category of concentration threshold for reasonableness, which ranged from 0.158-0.1598 ppm and 0.0233-0.2769 ppm
\end{abstract}

Keywords: Identifikasi, Logam Berat, Aliran Sungai, Ambang Batas

\section{PENDAHULUAN}

Komponen utama dan terpenting dalam mahluk hidup dan manusia adalah air. Manusia dan makhluk lain tak akan dapat melangsungkan proses kehidupan tanpa adanya air. Dalam Al-Quran surat Al-Anbiya ayat 30 Allah SWT berfirman: ... dan kami jadikan segala sesuatu yang hidup berasal dari air.. dengan kata lain, tak ada air, maka takkkan ada namanya kehidupan di muka bumi ini. Selain sebagai komponen dalam kehidupan, air juga menjadi kebutuhan pokok yang dipenuhi oleh setiap makhluk hidup. Kebutuhan itu haruslah tercukupkan. Bagi manusia kebutuhan air dapat digunakan dalam kebutuhan, minum, mencuci, mandi, dan kebutuhan lain.

Air yang baik menurut PP no 82 Tahun 2001 pada pasal 8 adalah adalah air yang terbagi atas 4 kelas standar baku mutu air. Selain dari PP tersebut berbagai hal perlu diperhatikan untuk mengetahui air layak atau tidak untuk dapat dikonsumsi. Air yang baik dan layak dikonsumsi harus memiliki kadar $\mathrm{pH}$ yang cukup, terhindar dari logam berat yang melewati ambang batas. $\mathrm{pH}$ air yang baik berkisar pada kisaran 6,9-8. Kondisi perairan yang tidak baik salah satunya di Rawapening, Kabupaten Semarang, Propinsi Jawa Tengah Menunjukkan bahwa terjadi penurunan kualitas air yang disebabkan residu pestisida dan sisa pupuk dari olahan pertanian, peternakan dan limbah domestik masyarakat (Hidayah, 2012)

Logam berat yang ada dan sering bersifat toksik atau Racun yaitu Timbal, Krom, Raksa, Uranium, Selenium, Seng, Arsen, kadnium, perak, emas, dan Nikel (Allury, 2007) Logam berat merupakan hasil samping dari peningkatan limbah industry yang dikategorikan beracun dan berbahaya (Rochyatun, 2006). Logam berat yang ada bisa datang dari berbagai sumber seperti industri 
perkotaan, limbah padat hewan, aktivitas tambang, industri kimia dan pertanian (Allury, 2007).

Keberadaaaan limbah-limbah industri yang dibuang ke sungai yang mengandung logam berat sangat berbahaya baik bagi manusia, hewan maupun lingkungan (Karamah, 2008) . Hal ini menyebabkan sungai yang ada salah satunya di Sungai Batang Kuantan juga ikut terdampak.

\section{METODE PENELITIAN}

Air sampel diambil pada aliran sungai dengan menggunakan pemberat. Sampel yang telah dipipet sebanyak $50 \mathrm{~mL}$ kemudian dipindahkan ke dalam beaker $250 \mathrm{~mL}$. Setelah itu, ditambahkan $5 \mathrm{~mL} \mathrm{HNO}_{3}$ pekat. Sampel dipanaskan di atas hot plate hingga volume menjadi $20 \mathrm{~mL}$. pindahkan ke dalam labu ukur $50 \mathrm{~mL}$ dan tambahkan dengan air hingga tanda batas. Analisis dengan AAS (Arief, 2012). Data Hasil Analisis logam berat dibandingkan dengan baku mutu peraturan pemerintah no 82 tahun 2001 tentang pengelolaan kualitas air dan pengendalian pencemaran air

\section{HASIL DAN PEMBAHASAN}

1. Hasil Pengamatan $\mathrm{pH}$

Dari PH yang diamati didapatkan bahwa $\mathrm{pH}$ yang berada pada perairan di sepanjang aliran sungai batang kuantan kabupaten kuantan singingi masih berada dalam taraf normal yakni 6,9-7,0. $\mathrm{pH}$ air dengan kondisi ini menyatakan bahwa tidak terdapat permasalahan yang berhubungan dengan $\mathrm{pH}$

2. Hasil pengamatan Logam Berat

Jadi, konsentrasi kadar $\mathrm{Pb}$ pada aliran sungat batang kuantan bernilai (-) atau tidak teridentifikasi

Jadi, konsentrasi kadar Cd pada aliran sungai batang kuantan bernilai $0,15827 \mathrm{ppm}$ di lubuk jambi, 0,15947 ppm di teluk kuantan dan 0,1598 ppm di benai.

Jadi, konsentrasi kadar $\mathrm{Cu}$ pada aliran sungai batang kuantan bernilai 0,2769 ppm di lubuk jambi, 0,0110 ppm di teluk kuantan dan 0,0233 ppm di benai
Analisis kandungan Logam seperti $\mathrm{Pb}$ sangat penting, $\mathrm{Pb}$ berbahaya bagi manusia karena bersifat karsinogenik dan beracun. Timbal masuk ke dalam tubuh manusia dapat menggangu sistem pusat syaraf hingga penurunan IQ seseorang. Timbal yang mengenai kulit dapat mengakibatkan iritasi pada kulit dan jika terhirup menyebabkan kanker pada paru-paru. $\mathrm{Pb}$ yang diteliti tidak terdeteksi pada aliran Sungai Batang Kuantan Kabupaten Kuantan Singingi. Tabel hasil pengamatan $\mathrm{Pb}$ dapat dilihat pada Tabel 1 .

Table 1. Tabel Hasil Pengamatan $\mathrm{Pb}$.

\begin{tabular}{cc}
\hline Konsentrasi & Absorbansi \\
\hline $0 \mathrm{ppm}$ & $-0,0001$ \\
$2 \mathrm{ppm}$ & 0,0082 \\
$4 \mathrm{ppm}$ & 0,0086 \\
$6 \mathrm{ppm}$ & 0,0160 \\
$8 \mathrm{ppm}$ & 0,0232 \\
$10 \mathrm{ppm}$ & 0,0306 \\
Air sungai di & $-0,0023$ \\
Lubuk Jambi & \\
Air sungai di & $-0,0026$ \\
Teluk Kuantan & \\
Air sungai di & $-0,0030$ \\
Benai &
\end{tabular}

Hal yang berbeda terjadi pada $\mathrm{Cu}$ karena konsentrasi kadar $\mathrm{Cu}$ pada aliran sungai batang kuantan bernilai 0,2769 ppm di lubuk jambi, 0,0110 ppm di teluk kuantan dan 0,0233 ppm di benai. Meskipun terdeteksi namun masih dalam kategori yang tidak membahayakan. Hasil Analisis $\mathrm{Cu}$ dapat dilihat pada Tabel 2.

Table 2. Tabel Hasil Pengamatan Cd.

\begin{tabular}{cc}
\hline Konsentrasi & Absorbansi \\
\hline $0 \mathrm{ppm}$ & $-0,0002$ \\
$2 \mathrm{ppm}$ & 0,1962 \\
$4 \mathrm{ppm}$ & 0,3742 \\
$6 \mathrm{ppm}$ & 0,5221 \\
$8 \mathrm{ppm}$ & 0,6515 \\
$10 \mathrm{ppm}$ & 0,7535 \\
Air sungai di & 0,0007 \\
Lubuk Jambi & \\
Air sungai di & 0,0010 \\
Teluk Kuantan & \\
Air sungai di & 0,0011 \\
Benai &
\end{tabular}


Hal yang sama juga terjadi pada logam $\mathrm{Cd}$ yang djuga terdeteksi pada aliran sungai bilangan angka yang kecil membuat $\mathrm{Cd}$ juga masih dalam taraf aman. Hasil Analisi Cd dapat dilihat pada Tabel 3 .

Table 3. Tabel Hasil Pengamatan $\mathrm{Cu}$.

\begin{tabular}{cc}
\hline Konsentrasi & Absorbansi \\
\hline 0 ppm & 0,0002 \\
$2 \mathrm{ppm}$ & 0,0398 \\
$4 \mathrm{ppm}$ & 0,0822 \\
$6 \mathrm{ppm}$ & 0,1256 \\
$8 \mathrm{ppm}$ & 0,1659 \\
$10 \mathrm{ppm}$ & 0,2065 \\
Air sungai di & 0,0379 \\
Lubuk Jambi & \\
Air sungai di & 0,0011 \\
Teluk Kuantan & \\
Air sungai di & 0,0028 \\
Benai &
\end{tabular}

Dari hasil analisis didapatkan konsentrasi kadar $\mathrm{Pb}$ pada aliran sungat batang kuantan bernilai (-) atau tidak teridentifikasi. Sedangkan konsentrasi kadar Cd pada aliran sungai batang kuantan bernilai rerata 0,15827 ppm di lubuk jambi, 0,15947 ppm di teluk kuantan dan 0,1598 ppm di benai. Konsentrasi kadar $\mathrm{Cu}$ pada aliran sungai batang kuantan bernilai 0,2769 ppm di lubuk jambi, 0,0110 ppm di teluk kuantan dan 0,0233 ppm di benai. Di sini di dapatkan bahwa dibandingkan dengan baku mutu kelas 3 peraturan pemerintah no 82 tahun 2001 tentang pengelolaan kualitas air dan pengendalian pencemaran air tidak terdapat permasalahan yang berarti bagi $\mathrm{Pb}$. Namun, untuk $\mathrm{Cd}$ dan $\mathrm{Cu}$ dalam kategori ambang batas.

\section{SIMPULAN}

PH yang diamati didapatkan bahwa $\mathrm{pH}$ yang berada pada perairan di sepanjang aliran sungai batang kuantan kabupaten kuantan singingi masih berada dalam taraf normal yakni
6,9-7,0. Konsentrasi kadar $\mathrm{Pb}$ pada aliran sungat batang kuantan bernilai (-) atau tidak teridentifikasi. Konsentrasi kadar Cd pada aliran sungai batang kuantan bernilai rerata 0,15827 ppm. Konsentrasi kadar Cu pada aliran sungai batang kuantan bernilai 0,0110-0,2769 ppm.

\section{REFERENSI}

Alluri, Hima Karnika, Srinivasa Reddy Ronda, Vijaya Saradhi Settalluri, Jayakumar Singh, Bondili, Suryanarayana. $V$ and Venkateshwar. P. 2007. Biosorption An Eco-friendly Alternative for Heavy Metal Removal. African Journal of Biotechnology Vol. 6 (25), pp. 2924-2931.

Arief Happy R, Masyamsir dan Yayat Dhahiyat. 2012. Distribusi Kandungan Logam Berat Pb dan Cd pada Kolom Air dan Sedimen Daerah Sungai Citarum Hulu. Jurnal Perikanan 3(3), pp 175-182

Hidayah, Anny Miftakhul, Purwanto dan Tri Retnaningsih Soeprobowati. 2012. Kandungan Logam Berat Pada Air, Sedimen dan Ikan Nila (Oreochromis niloticus Linn.) di Karamba Danau Rawapening. Prosiding Seminar Nasional Pengelolaan Sumberdaya Alam dan Lingkungan di Semarang, 11 September 2012

Karamah, Eva Fathul, Setijo Bismo, dan Hotdi M. Simbolon. 2008. Pengaruh Ozon dan Konsentrasi Zeolit terhadap Kinerja Proses Pengolahan Limbah Cair yang Mengandung Logam dengan Proses Flotasi. Makara Teknologi Vol. 12 (1), pp 4347

PP No 822001 tentang Pengelolaan Kualitas Air dan Pengendalian Pencemaran Air

Rochyatun, Endang, M. Taufik Kaisupy dan Abdul Rozak. 2006. Distribusi Logam Berat dalam Air dan Sedimen di Perairan Muara Sungai Cisadane. Makara Sains Vol. 10 (1), pp 35-40 